\title{
Public service in Nigeria: Perception of young and middle-aged adults
}

\author{
Isaac Akintoyese Oyekola ${ }^{1,2}$ Oludele Albert Ajani ${ }^{3}$ Festus Femi Asamu $^{1,2}$ \\ Oluyinka Olutola Olajire ${ }^{4}$
}

\footnotetext{
${ }^{1}$ Department of Sociology, Landmark University, Omu-Aran

${ }^{2}$ Landmark University SDG 10 (Reduced Inequalities), Landmark University, Omu-Aran, Nigeria

${ }^{3}$ Department of Sociology and Anthropology, Obafemi Awolowo University, Ile-Ife

${ }^{4}$ Department of Behavioural Studies, Redeemer's University, Ede

Correspondence: oyekola.isaac@1mu.edu.ng
}

\begin{abstract}
The purpose of this study is to assess the perception of public service in Nigeria from the standpoint of young and middle-aged adults in Ibadan, Nigeria with a view to determining its performance and contribution to national development. Concurrent triangulation mixed methods research design was adopted in this study to collect primary data from young and middle-aged adults in Ibadan, Nigeria. Descriptive and inferential statistics described quantitative data and principal component analysis extracted two factors. In addition, thematic content analysis was adopted to analyze qualitative research data. Findings showed that respondents had negative perception of public service in Nigeria both in terms of its operation and reward. Job security was perceived positively but corruption/bad behaviour in the public service was most perceived negatively. Also, final year undergraduates most perceive public service negatively and public paid workers least perceived public service negatively. Knowledge of this study will benefit Nigerians who render and enjoy public services, and will be most useful for the Nigerian public service to formulate policies that will prevent selfinterested, inefficient, ineffective and unproductive public service workforce. This study measures, for the first time, perception of Nigerian public service in terms of its operation and reward. Studies that will investigate the rationale behind young and middle-aged adults' negative perception of and high preference for careers in Nigerian public service are recommended. Also, improvement in service delivery and in the conditions of Nigerian public service will help in correcting the negative view.
\end{abstract}

Keywords: Perception of public service, public sector, Nigerian youths and middle-aged adults, development studies, Sociology

\section{Background}

The role of public service towards the attainment of national development cannot be underrated in a dynamic and rapidly changing Nigerian society. In developing countries, particularly in Nigeria, public service is the most significant catalysts of national development (Eneanya, 2018) and remains a preferred choice of career for many young and middle-aged adults (Ajani \& Oyekola, 2019; Barsoum, 2015). In the same manner, the inefficiency and ineffectiveness of public service constitute a major setback of any country. Generally, any service provided or supported by the government or its agencies is considered public service. If public service encompasses all services that are rendered or funded by the government or its representatives and/or agencies, and if government remains the final hope for the majority timid and vulnerable Nigerian population, then its assessment is crucial in determining its performance and contribution to national development.

In pre-colonial Nigerian society, careers define people's identity. During this epoch, people engaged mostly on land as their primary occupations while jobs in the manufacturing or service industries were seen as auxiliary (Johnson, 2010; Olugbile, 1997; Oyekola, 2017). Occupations 
in these pre-colonial societies were within the scope of primary stage of production; although this was not to suggest that agriculture was the only career available to Nigerian youths in the pre-colonial society. One unique feature of the people's careers before the contact with the Europeans was that there was no such thing as seeking paid employment (Oyekola, 2017). Freeborn individual did not voluntarily sell his labor (as obtained in capitalism), although he may be eligible to receive assistance from his peers or relatives on the basis of mutual reciprocity. Careers in pre-colonial society developed outside the atmosphere in which our work orientation today was situated, and was an essential part of people's way of life. It would be correct to say that in pre-colonial society when a person worked, his loyalty was either to himself as a self-employed person or to his leader (such as Oba, Clan Leader or Emir) or some other higher placed person for whom he labored. Either way, the target of the loyalty was a living, breathing entity. The type of careers young and middle-aged adults in pre-colonial Nigerian society engaged in was often hereditary (Johnson, 2010). There was no rivalry competition among the youths in seeking paid employment (because available jobs in the informal sector were far more than the number of youths) until the importation of wage employment due to globalization process (Oyekola, 2018; Oyekola \& Olajire, 2020), which became widely recognized through the establishment of public services.

In the year 1914, the Southern and Northern Protectorates were amalgamated and this engenders a burgeoning public sector (and private sector) careers. The public services were then set up both in the North and South headed by Lieutenant Governors. All the original officers of the two public services were expatriate managers (Johnson, 2010; Oyekola, 2017). At this time, indigenous people of Nigeria occupied low rank positions. After less than a decade of the introduction of this system of administration, educated Nigerians, led by Herbert Macauley (the Father of Nigerian nationalism), started challenging the status quo. As a group, they agitated greater political and administrative participation in the nation's affairs. The outcome of this was the birth of the first constitution ever recorded in the history of the country: Clifford Constitution of 1922. The subsequent constitutions increased Nigerian participation in government as a whole. At the wake of federalism in the year 1954, Nigeria took on federal structure having three regions and public services were established at the centre of each region (Nkwede, 2013). At the time, both the federal and regional governments encouraged careers in public service. It is important to note that up till the end of the first republic in 1966, Nigerian public services were direct resemblance of that of the British administrative structure in terms of operations, rewards, training and development, ethics and espirit de corps (Anazodo et al., 2012). During this period, public services were established at the Federal and regional (which include Northern, Eastern, Western and Mid-Western) levels. As at this time, Nigerians began to be more visible occupying the front-seat in public service and, concurrently, started looking down on agriculture (Olugbile, 1997).

With the oil boom and the resultant abundant wealth in the 1970s, more commitment towards the advancement of the Nigerian economy was recorded. This resulted in the creation of states in replacement of regions. Since then, both the federal and state public services have witnessed unprecedented growth and in the process, have undergone series of reforms, to be able to meet their increasing responsibilities (Anazodo et al., 2012; Ijewereme, 2018; Oyekola, 2017). Today, Nigeria is a country with a very large public service, having thirty-six states along with a federal capital territory. Apart from the federal civil service, each state government operates its own civil service. There are also many parastatals (utilities), ministries, commissions and agencies established by the federal and state governments. There are also many local governments (known as the third tier of government) in all the states with their own structures extending through all the nooks and crannies of the country. Aside providing services for the 
general populace, these public services offer enlarged opportunities for the teeming young and middle-aged adults to pursue their careers and to seek paid employment.

\section{Literature Review}

With the understanding that good operational and provisional system in the public service is vital for any nation's development (Ferguson, 2019; Marshall \& Murtala, 2015), it is imperative to gain further understanding of the perception of Nigerian public service. This is significant for assessing the performance of public service in Nigeria and also to determine its contribution to national development. Recently, government reports of parastatals, ministries, commissions and agencies seem to deviate from public perceptions of governmental performances. Yet, public assessment of the public service remains viable democratic tool to arrive at objective evaluation. Perception of public service varies geographically and historically across the globe. Report by the Crime and Misconduct Commission (2011) in Australia, for instance, shows positive perception of public service among employees. Similar positive views were reported in other developed nations especially in terms of performance, service delivery and reward system (Magdahl \& Jordhus-Lier, 2020; Suebvises, 2018; Hospido \& Moral-Benito, 2016; Lægreid et al., 2013), although few of these reports show that the public still believed in the continuous existence of corrupt practices in the public service and as a result, expect more attention on the issue (Mocetti \& Orlando, 2019; Crime and Misconduct Commission, 2011).

In many developing countries, Nigeria inclusive, many studies have given attention to the issue of corrupt practices in the public service and how it has affected productivity, service delivery, operational and reward system (Gordon, 2017; Okech, 2016; Ijewereme, 2015; Marshall \& Murtala, 2015; Inyang \& Akaegbu, 2014; Yeboah-Assiamah et al., 2014; Olugbile, 1997). The African Capacity Building Foundation (ACBF, 2007), further stated that the level of corruption and bad behaviour in Nigeria is alarming, and a solid resentment against the public service are noticeable. It has also been noted that many Nigerians believed in the existence of corrupt practices which have pervaded all nooks and corners of the state, and that it was virtually impossible to benefit from public service without one form of corrupt practice or the other (Imhonopi \& Ugochukwu, 2013). Few studies which attempted to assess public service beyond the level of corruption focused on preference for public sector careers, attitude and commitment to work, pay scheme, and service delivery (Ajani \& Oyekola, 2019; Adisa, 2011; Olugbile, 1997). However, these yardsticks were not adequate to appraise young and middle-aged adults' perception of Nigerian public service. This study therefore sets to assess young and middleaged adults' perception of Nigerian public service in terms of working condition, pay scheme, training and education, job security, promotion, and supervision, among others with a view to evaluating its performance and determining its contribution to national development.

\section{Methodology}

\subsection{Study location}

Perception of public service was investigated in Ibadan metropolitan city of Nigeria. Ibadan $(3,080 \mathrm{sq} \mathrm{km})$, with a population of over 3 million, is ranked the largest urban geographical region in Nigeria (Central Intelligence Agency, 2020). The city, which is an important trade and commercial centre, is located in South-western geographical zone in Nigeria (Oyekola \& Olajire, 2020), and it houses the first university in Nigeria known as the University of Ibadan. It also houses local, state and federal secretariats as well as many federal government parastatals, ministries, commissions and agencies, all providing public services to the general populace. 


\subsection{Instrumentation}

Perception of public service questionnaire (PPSQ) and perception of public service interview guide (PPSIG) were developed and used as research instruments for this study. The PPSQ consisted of 10 items and the PPSIG consisted of targeted questions on perception of public service. The items on the PPSQ and the questions on the PPSIG were derived from existing literature that assessed public service both in the developed and developing countries (Ajani \& Oyekola, 2019; Ferguson, 2019; Hailu \& Shifare, 2019; Masiya et al., 2019; do Monte, 2017; Oke \& Asamu, 2013; Kumari \& Pandey, 2011; Khan \& Din, 2008).

\subsection{Instruments' validation and reliability}

To ascertain the validity of PPSQ and PPSIG, two different academic experts in sociology and public administration were requested to review the items on the PPSQ and the questions on the PPSIG. This resulted in correcting the grammar of some items and questions, changing the structure of some and removal of some others. In addition, to estimate the internal consistency of the 10-item PPSQ-scale, a pilot study was conducted on fifty young and middle-aged adults who were not within the sample area. After reversing the coding of the negative items on the scale, Cronbach's alpha was .903, an indication that excellent degree of reliability existed among the items (Yockey, 2017; Kline, 1999) and therefore good enough for the study.

\subsection{Sampling, Data collection and Scoring}

This study sampled 505 respondents and 6 interviewees using quota and purposive sampling techniques respectively. Using concurrent triangulation mixed methods research design which involves simultaneous collection of qualitative and quantitative research data, both PSSQ and PPSIG were self-administered by the researchers in different study sites with the help of gate keepers after being granted permission. Respondents were asked the extent of their disagreement or agreement with each item on the Likert-type PPSQ-scale. After sorting out the items, eight positive items were scored accordingly (4=strongly agree, $3=$ agree, $2=$ disagree and $1=$ strongly disagree) while scoring of the two negative items were reverse coded before analyzing the data. Respondents were given assurance to treat their honest responses with all degree of confidentiality and to use such responses only as data for research work.

\subsection{Analysis}

Frequencies of the study sample were first analyzed to determine the numbers and percentages of observation in each category of sociodemographic variables (respondents' categories, sex, age, and education). A measures of central tendency (mean) was analyzed to describe the average score of each category of sociodemographic variables in order to determine the level of agreement or disagreement with the 10-item PPSQ-scale. A measure of variability (standard deviation) was used to measure how far, on average, each score varies from the mean. Furthermore, descriptive statistics (with the use mean, median and standard deviation) of each item on the PPSQ-scale was carried out to determine respondents' view on each of the items. Kaiser-Meyer-Olkin Measure of Sampling Adequacy and Bartlett's Test of Sphericity were carried out to examine the adequacy of the study sample for analysis and the existence of some significant relationship among the 10-item PPSQ-scale respectively. Principal component analysis was then performed to determine the factor structure of the PPSQ-scale. Factors were extracted based on eigenvalues greater than 1 . Orthogonal rotation method was applied to the initial factors using varimax with Kaiser Normalization because no theoretical basis exists for the correlation of the factors. To determine whether the means of the factor structures were significantly different from the mean of PPSQ-scale, one-sample $t$-test was carried out. A more 
commonly used effect size of Cohen's $d$ which calculate the amount of difference between the sample mean and the population mean in terms of standard deviation units was utilized (Yockey, 2017; Cohen, 1988). Lastly, oneway ANOVA was carried out to compare the means of factor structure and their statistical significance across sociodemographic variables.

\section{Results}

The results showed equal representation of final year undergraduates, fresh graduates, public and private paid workers, as well as self-employed people. Slightly more males (51.3 percent) were represented in the study and majority (91.7 percent) of the respondents had tertiary education. The average age of the respondents was 30 years, with 7.06 as standard deviation. Also, the mean age of the interviewees was 48 years and it ranges between 37 years and 57 years. Three of them were males, and all of them were married, had tertiary education and had spent above ten years in service.

Generally, the respondents had negative perception of the public service, as the overall mean (2.12) was not up to the average mean of 2.5, thereby indicating that the respondents disagreed with the items on PPSQ (see Table 1). More importantly, respondents with primary level of education and final year undergraduates had more negative view of public service as indicated in their mean values of 1.85 and 1.95 respectively. The low standard deviations of these two categories of respondents further indicated that most of the respondents in these categories were of the same opinion. However, the views of those who were between the ages of 31 and 35 years, as well as public paid workers were better off, although still negative.

As earlier mentioned, 10-item scale was used to measure perception of public service and items number 6 and 7 have been reverse coded. The first, second, ... and tenth items were labelled $\mathrm{q} 1, \mathrm{q} 2, \ldots \mathrm{q} 10$ respectively. The mean and standard deviation of each item on the PPSQ were generated in order to assess the perception of respondents on each of the items. Respondents most agreed that 'high rate of corruption/bad behaviour is recorded in the Nigerian public service' and disagreed that 'recruitment into Nigerian public service is solely based on merit', as these particular items had the lowest mean values of 1.83 and 1.88 respectively. However, from Table 2, it is evident 'there is job security in the Nigerian public service' as respondents most agreed to that, given the mean and median values to be 2.86 and 3 respectively. In fact, the fourth item - 'there is job security in the Nigerian public service'- was the only item that generated positive perception from the respondents, as respondents negatively perceived all other nine items, although in different degrees. The qualitative method of inquiry investigated the perception of Nigerian public service in terms of non-monetary and monetary rewards. The data showed that poor pay characterized public service and that public servants were not well remunerated. "Public service is not attractive in term of monetary reward." Although it was acknowledged that public service had job security, peace of mind, and is not too demanding, the take home is not attractive. "But in term of non-monetary reward, may I say it is not too demanding, I have job security, I have peace of mind, even though the money is not much but at least, I have that peace." Also, "the monthly stipend or leave bonus, and some other remunerations cannot be compared to that of the private sector [which is better off]". Hence, in term of monetary reward, the Nigerian public service is nothing to write home about: it is not good enough and not encouraging.

Table 3 presents the results of the principal component analysis (PCA) that was carried out on the PPSQ. The sampling adequacy was verified by the Kaiser-Meyer-Olkin (KMO) measure as the result showed that KMO was 0.92, a value considered to be 'superb' (Field, 2009). Also, the Anti-Image Correlation showed the value of KMO for each individual item on the PPSQ which ranged from 0.67 for $\mathrm{q} 4$ to 0.94 for $\mathrm{q} 2$, values considered to be above the acceptable 
limit of 0.5 (Yockey, 2017; Field, 2009). The results of the Bartlett's test of sphericity $\left[\chi^{2}(45)\right.$ $=4619.00, p<.001]$ showed that relationships existed between the variables to be used for analysis and that the correlation matrix was not an identity matrix. In addition, using Kaiser's criterion of eigenvalues greater than 1, two factors were extracted and in combination, both factors explained 76.16 per cent of the total variance. Specifically, the two extracted factors (F1 and F2) accounted for 63.4 per cent and 12.8 per cent of the variance in the data (before rotation) and 47.5 per cent and 28.636 per cent respectively (after rotation). This indicates that most of the items on the PPSQ-scale load highly on first component before rotation but after rotation, the loadings were spread and the second factor received more loadings. The items that cluster on the Factor 1 ('high rate of corruption/bad behaviour is recorded in the Nigerian public service', 'there is high record of lateness in the Nigerian public service', 'there is high productivity, effectiveness and efficiency in Nigerian public service', 'recruitment into Nigerian public service is solely based on merit', and 'workers in the Nigerian public service are strictly supervised') represents operation of the public service and the items that cluster on the Factor 2 ('there are provisions for training and education in Nigerian public service', 'workers are promptly promoted in the Nigerian public service', 'good working conditions are well provided in the Nigerian public service', 'public workers are paid more than any other categories of workers in Nigeria', 'there is job security in the Nigerian public service') signifies reward in the public service. A reliability analysis was caried out on the two extracted factors. The operation of the Nigerian public service and the reward in the Nigerian public service subscales of the PPSQ both had high reliabilities and all Cronbach's $\alpha=0.92$ was considered good enough (Yockey, 2017; Cohen, 1988). None of the items on PPSQ-scale, if deleted, would considerably affect reliability since no value is significantly different from Cronbach value of all the ten items.

The results of the one-sample $t$-test, as presented in Table 4, show that the mean of operational system (1.93) in the public service was significantly smaller than the mean of the population (2.12), $t(504)=-6.06, p<0.001, d=-.27$, thereby indicating that respondents perceived the operation of the public service in a more negative light than the total perception of Nigerian public service. Also, in term of the reward system in the Nigerian public service, the mean value (2.30) was significantly larger than the total mean value of the perception of Nigerian public service $(2.12), t(504)=6.294, \mathrm{p}<0.001, d=.28$. This shows that respondents were less negative about the reward system in the public service than the general perception of the public service. The low value of the standard errors showed that most respondents across extracted factors had very similar means, and the mean difference showed the difference between sample means and population mean.

Oneway Analysis of Variance (ANOVA) test established statistical significance between sex and reward system in the public service $(\mathrm{p}<.05)$ but contrary evidence was noted between sex and operation of the public service $(\mathrm{p}>.05)$. Hence, the mean difference between male and female respondents' perception of public service in term of operational system was not significant; rather, it was significant in term of reward system. The test further established statistical significance between categories of occupation and operation of the public service $(p$ $<.001)$ as well as between categories of occupation and reward system in the public service ( $\mathrm{p}$ $<.05)$. Therefore, males had more negative perception of the public service in term of reward system $(M=2.24)$ than their female counterpart $(M=2.36)$. Also, among the categories of occupation, final year undergraduates had the most negative view of the public service in terms of its operation and reward $(\mathrm{M}=1.73$ and 2.17 respectively) compare to the public paid workers who had the least negative perception of the operation of and reward in the public service (M $=2.21$ and 2.42 respectively). The details are presented in Table 5 . 


\section{Discussions of Findings}

It can be established that the respondents had negative perception of Nigerian public service. Final year undergraduates had more negative view of public service than any other categories of respondents. Final year undergraduates might have been informed about the operation of public service, which might have in turn affected their perception of the service. However, as they began to face the reality of unemployment immediately after graduation, they tended to appreciate public service as an alternative pathway to career development. This probably made fresh graduates to be more optimistic about the public service than the final year undergraduates, although not as the public paid workers. Public paid workers represented the proportion of respondents' categories who had the least negative perception of public service. Since they were working therein, they were probably encouraged to perceive public service in a less negative light. These findings are in line with existing studies which reported negative view of public service among Nigerians (Adisa, 2011; Olugbile, 1997). Generally, negative perception of public service should engender low preference for public service. Notwithstanding, many Nigerians did not seem to deter from pursuing careers in the public service majorly because of job security (Ajani \& Oyekola, 2019).

Job security is the only item in the PPSQ-scale that was perceived in a positive light among the respondents. According to Ajani and Oyekola (2019), job security is considered a major factor in considering a career in the public service because of the social costs involve in losing a job and the effects such costs have on the concerned individual as well as her/his extended family. In addition, among the ten items on the PPSQ-scale, respondents most agreed that 'high rate of corruption/bad behaviour is recorded in the Nigerian public service' as the item stood out among the items that contributed to negative perception of public service. It is noteworthy that issues surrounding corruption in the Nigerian public service have already been established in the literature (Ani Casimir et al., 2009; Ijewereme, 2015; Imhonopi \& Ugochukwu, 2013; Oyekola, 2017). This study therefore confirms that corruption exists in the Nigerian public service and this contributes to negative perception of Nigerian public service, especially in term of its operation. Next in order, the respondents disagreed that 'recruitment into the Nigerian public service is solely based on merit'. Favoritism/nepotism, a rampant phenomenon, is one of the challenges confronting public service in Nigeria, and it has resulted in various unfair recruitment process (Longe, 2017; Ijewereme, 2015; Nkwede, 2013). This had often made some succeeding governments to embark on retrenchment of workers previously employed by preceding administrations. Hence, both corruption and unfair recruitment process contributed majorly to negative perception of public service in Nigeria.

Perception of Nigerian public service was further categorized into operational and reward system. Generally, respondents were somewhat more negative about how public service operates (in terms of corruption, lateness to work, low productivity, unfair recruitment process, and low supervision) than the reward the public service offers (in terms of low provision for training and education, delayed promotion, poor working condition, low remuneration, and job security). Consequently, negative perception of public service in term of its operation is higher than the negative perception of public service in term of its reward, but lower than the general negative perception of public service. Hence, respondents were less negative about the reward system in the public service than the general perception of public service. This may account for the eventual preference for public sector jobs (Ajani \& Oyekola, 2019; Barsoum, 2015). Also, it can as well be established that many young and middle-aged adults were after the rewards the service offers and not majorly for altruistic service motive. Otherwise, they would have been deterred from pursuing careers in the public service immediately they develop negative perception of it. Since the service attracts self-interested individuals therefore, the 
implication is inefficient and ineffective service delivery resulting in low productivity in the public service (Olugbile, 1997). Hence, the need for total restructuring of the public service in other to attain desired national development (Nkwede, 2013).

Males had more negative perception of the public service in term of reward system than their female counterpart. Having established that public service pays less in term of monetary reward but offers job security, males might be influenced by the monetary reward and females by job security to determine their perception of public service. This is so because men's desire are geared towards meeting their financial responsibilities while women generally desires security (Eckel \& Grossman, 2008). Also, among the categories of respondents, final year undergraduates had the most negative view of the public service in terms of its operation and reward compare to the public paid workers who had the least negative perception of the operation of and reward system in the public service. Final year undergraduates are highly financially ambitious and therefore rule out the possibility of seeking careers in the public sector since it offers meagre financial reward (Okojide et al., 2018; Koech et al., 2016). Also, although public paid workers were not well remunerated, they still perceived public service less negatively because they tend to enjoy job security, not minding the little monetary reward. In term of the operation of the public service, public paid workers represented least proportion and final year undergraduates typified the highest proportion of respondents' categories who had negative perception of public service. Public paid workers truly speak well of their jobs. This is because they see themselves as less corrupt, coming early to work, demonstrating effectiveness in service delivery, and operating on merit basis. The findings in this study disconfirm such similar findings in developed countries which reported positive perception of public service (Australia, Crime and Misconduct Commission, 2011). However, the findings from this study confirm studies from developing countries. For example, negative perception of public service was reported in Bangladesh, Central Asia (Monem \& Baniamin, 2017; Public Officials Surveys, 1999). Also, the findings confirm similar studies in Nigeria which affirmed that Nigerian public service is overwhelmed with many ills, thereby creating negative perception of public service among the young and middle-aged adults (Ijewereme, 2015; Imhonopi \& Ugochukwu, 2013; Adisa, 2011; Olugbile, 1997).

\section{Conclusion and recommendations}

There is negative perception of the Nigerian public service and this negative perception was higher in term of its operation than in term of its reward. Improvement in operation of public service will help in correcting this negative perception. Since public service remains viable channel for national development, this study recommends restructuring of key areas in the public service that will reduce corrupt practices and ensure fair recruitment process so as to make it more efficient and effective. This in turn will encourage positive perception of public service thereby attracting best brains and selfless individuals who are capable of championing development in the nation.

\section{Future research}

This study has measured, for the first time, the perception of Nigerian public service in terms of its operation and reward among the young and middle-aged adults in Ibadan, Nigeria. Although one might hypothesize that negative perception of public service will engender low preference for public sector jobs, evidence from the literature confirms otherwise. Studies that will investigate the rationale behind negative perception of and high preference for careers in the Nigerian public service are therefore recommended. Future research should be extended to other areas not covered in the study and involve top management officials for comparative analysis. 


\section{References}

Adisa, A. L. (2011). Current State of the Economy and Obafemi Awolowo Univesity Students' Assessment of the Image of the Nigerian Civil Service. Ife PsychologIA, 19(1), 328-341. https://doi.org/https://doi.org/10.4314/ifep.v19i1.64606

Ajani, O. A., \& Oyekola, I. A. (2019). Reasons for Public Sector Jobs Preference in Nigeria. African Research Review, 13(1), 114-130. https://doi.org/http://dx.doi.org/10.4314/afrrev.v13i1.11

Anazodo, R. O., Okoye, J., \& Chukwuemeka, E. E. O. (2012). Civil service reforms in Nigeria: The journey so far in service delivery. American Journal of Social and Management Sciences, 3(1), 17-29. https://doi.org/10.5251/ajsms.2012.3.1.17.29

Ani Casimir, K. C., Izueke, E. M., Nzekwe, I. F., \& Casimir, K. C. A. (2009). Public Sector and Corruption in Nigeria: An Ethical and Institutional Framework of Analysis Keywords Public Sector, Ethics, Values, Corruption, Institutional Reforms, Institutions Fighting Corruption in Nigeria-ICPC, EFCC, Code of Conduct Bureau \& NAFDAC. Open Journal of Philosophy, 4(4), 216-224. https://doi.org/10.4236/ojpp.2014.43029

Barsoum, G. (2015). Young People's Job Aspirations in Egypt and the Continued Preference for a Government Job. In R. Assaad \& C. Krafft (Eds.), The Egyptian Labour Market in an Era of Revolution. Oxford University Press. https://doi.org/https://doi.org/10.1093/acprof:oso/9780198737254.003.0006

Central Intelligence Agency. (2020). Nigeria Demographics Profile. The World Factbook. Africa: Nigeria. https://www.cia.gov/library/ publications/resources/the-worldfactbook/geos/ni.html

Cohen, J. (1988). Statistical power analysis for the behavioral sciences (2nd ed.). Routledge. https://doi.org/https://doi.org/10.4324/9780203771587

Crime and Misconduct Commission. (2011). Public perceptions of the public service: findings from the 2010 Public Attitudes Survey. In Public perception series.

do Monte, P. A. (2017). Public versus private sector: Do workers' behave differently? EconomiA, 18, 229-243. https://doi.org/10.1016/j.econ.2017.01.001

Eckel, C. C., \& Grossman, P. J. (2008). Differences in the economic decisions of men and women: Experimental evidence. Handbook of Experimental Economics Results, 1, 509519. https://doi.org/https://doi.org/10.1016/s1574-0722(07)00057-1

Eneanya, A. N. (2018). Performance management system and public service delivery in Nigeria: Impacts, problems, challenges and prospects. Africa's Public Service Delivery and Performance Review, 6(1), 1-9.

https://doi.org/https://doi.org/10.4102/apsdpr.v6i1.201

Ferguson, B. (2019). Public Administration Performance Measurement. In Competing for Influence: The Role of the Pulblic Service in Better Government in Australia (pp. 127165). ANU Press. https://doi.org/https://doi.org/10.22459/ci.2019

Field, A. (2009). Discovering Statistics Using SPSS (3rd editio). Sage Publications Ltd. 
Gordon, M. B. (2017). Bribery and corruption in public service delivery: Experience from the Ghana Judicial Service. https://doi.org/https://doi.org/10.2139/ssrn.2922519

Hailu, A. G., \& Shifare, H. G. (2019). Service Delivery and Customer Satisfaction in the Public Service Sector: An Ethiopian Experience. Public Policy and Administration Research, 9(9), 24-37. https://doi.org/https://doi.org/10.7176/ppar/9-9-04

Hospido, L., \& Moral-Benito, E. (2016). The public sector wage premium in Spain: Evidence from longitudinal administrative data. Labour Economics, 42(2016), 101-122. https://doi.org/10.1016/j.labeco.2016.08.001

Ijewereme, O. B. (2015). Anatomy of Corruption in the Nigerian Public Sector: Theoretical Perspectives and Some Empirical Explanations. SAGE Open, 5(2), 1-16. https://doi.org/10.1177/2158244015581188

Ijewereme, O. B. (2018). Civil service reforms and governance challenges in Nigeria. In Global encyclopedia of public administration, public policy, and governance (pp. 1-10). Springer, Cham. https://doi.org/https://doi.org/10.1007/978-3-319-31816-5_3535-1

Imhonopi, D., \& Ugochukwu, M. U. (2013). Leadership crisis and corruption in the Nigerian public sector: An albatross of national development. The African Symposium, 13(1), 7887. http://www.ncsu.edu/aern/TAS13.1/TAS13.1_Imhonopi.pdf

Inyang, B. J., \& Akaegbu, J. B. (2014). Redefining the Role of the Human Resource Professional (HRP) in the Nigerian Public Service for Enhanced Performance. International Journal of Business Administration, 5(1), 90-98. https://doi.org/10.5430/ijba.v5n1p90

Johnson, S. (2010). The History of the Yorubas: From the Earliest Times to the Beginning of the British Protectorate. Cambridge University Press. https://doi.org/https://doi.org/10.1017/cbo9780511702617

Khan, F. J., \& Din, M. U. (2008). Attitudes Towards Civil Service of Pakistan: A Perception Survey. The Pakistan Development Review, 47(4), 779-790. https://doi.org/https://doi.org/10.30541/v47i4iipp.779-790

Kline, P. (1999). The handbook of psychological testing (2nd editio). Routledge. https://doi.org/https://doi.org/10.4324/9781315812274

Koech, J., Bitok, J., Rutto, D., Koech, S., Okoth, J. O., Korir, B., \& Ngala, H. (2016). Factors influencing career choices among undergraduate students in public universities in Kenya: A case study of university of Eldoret. International Journal of Contemporary Applied Sciences, 3(2), 50-63. http://www.ijcar.net/assets/pdf/Vol3-No2February2016/03.pdf

Kumari, G., \& Pandey, K. M. (2011). Job Satisfaction in Public Sector and Private Sector : A Comparison. International Journal of Innovation, Management and Technology, 2(3), 222-228. https://doi.org/http://dx.doi.org/10.7763/IJIMT.2011.V2.135

Lægreid, P., Nordø, Å. D., \& Rykkja, L. H. (2013). Public Sector Reform in Norway: Views and Experiences from Senior Executives (Issue May). COCOPS. www.cocops.eu

Longe, O. (2017). Graduate Unemployment in Nigeria: Causes, Consequences and Remediable Approaches. American International Journal of Contemporary Research, 
7(4), 63-73. http://www.aijcrnet.com/journals/Vol_7_No_4_December_2017/8.pdf

Magdahl, J. E., \& Jordhus-Lier, D. (2020). Labour internationalism and the public sector: The case of the Public Services International. Political Geography, 79(2020), 102146. https://doi.org/10.1016/j.polgeo.2020.102146

Marshall, J. B., \& Murtala, A. M. (2015). Public Service in Nigeria- an Overview of Functions and Code of Conduct. Global Journal of Politics and Law Research, 3(1), 6169. https://doi.org/10.1017/CBO9781107415324.004

Masiya, T., Davids, Y. D., \& Mangai, M. S. (2019). Assessing Service Delivery: Public Perception of Municipal Service Delivery in South Africa. Theoretical and Emperical Researches in Urban Management, 14(2), 20-40.

Mocetti, S., \& Orlando, T. (2019). Corruption, workforce selection and mismatch in the public sector. European Journal of Political Economy, 60(2019), 101809. https://doi.org/10.1016/j.ejpoleco.2019.07.007

Monem, M., \& Baniamin, H. M. (2017). Public service ethics and corruption in Bangladesh. In Public Administration in South Asia (pp. 237-256). Routledge. https://doi.org/https://doi.org/10.1201/b14759-15

Nkwede, J. O. (2013). Public Sector Restructuring and Governance in Nigeria: Perspectives, Processes and Challenges. Journal of Business \& Management, 2(3), 32-44. https://doi.org/10.12735/jbm.v2i3p32

Oke, O. A., \& Asamu, F. F. (2013). Employees perspectives of workplace health promotion in selected institutions in Nigeria. JORIND, 11(1), 67-74. www.transcampus.org/journals; www.ajol.info/journals/jorind

Okech, B. B. (2016). Corruption and Service Delivery in Public Sector of Uganda: Causes and Consequences. Texila International Journal of Management, 2(2), 1-14. https://doi.org/https://doi.org/10.21522/tijmg.2015.02.02.art001

Okojide, A., Adekeye, O. A., \& Bakare, E. (2018). Factors influencing career choice among undergraduates in Covenant University, Nigeria. Proceedings of ICERI2018 Conference 12th-14th November. https://doi.org/https://doi.org/10.21125/iceri.2018.1496

Olugbile, F. (1997). Nigeria at Work (A Survey of the psychology of work among Nigerians). Malthouse Press Limited.

Oyekola, I. A. (2017). Sociological analysis of preference for public sector careers in Ibadan, Oyo State, Nigeria. Obafemi Awolowo University, Ile-Ife.

Oyekola, I. A. (2018). Culture and Globalisation. In O. A. Ogunbameru, A. L. Adisa, \& D. S. Adekeye (Eds.), Cross-cultural management: A multidisciplinary approach (pp. 81102). Obafemi Awolowo University Press. http://eprints.lmu.edu.ng/1410/1/Culture and GLobalisation CHAPTER 6.pdf

Oyekola, I. A., \& Olajire, O. O. (2020). 'Baranda': Structure and Praxis of 'Onibaranda' (Micro-Middlemen) in Yorubaland. Qualitative Market Research: An International Journal, In Press. https://doi.org/https://doi.org/10.1108/QMR-06-2020-0080

Public Officials Surveys. (1999). Draft for Consultation. Bangladesh: The experience and 
perceptions of public officials. Funded by the Bank Netherlands Partnership Program (BNPP) and managed by Phil Keefer (DECRG) and Pierre Landell-Mills (SASFP).

Suebvises, P. (2018). Social capital, citizen participation in public administration, and public sector performance in Thailand. World Development, 109(2018), 236-248. https://doi.org/10.1016/j.worlddev.2018.05.007

The African Capacity Building Foundation (ACBF). (2007). Institutional frameworks for addressing public sector corruption in Africa: Mandate, performance, challenges \& capacity needs. The African Capacity Building Foundation.

Yeboah-Assiamah, E., Asamoah, K., \& Osei-kojo, A. (2014). Corruption Here, Corruption There, Corruption Everywhere: A Framework for Understanding and Addressing Public Sector Corruption in Developing African Democracies. Journal of Public Administration and Governance, 4(3). https://doi.org/https://doi.org/10.5296/jpag.v4i3.6406

Yockey, R. D. (2017). SPSS Demystified: A Simple Guide and Reference (3rd ed.). Routledge. https://doi.org/https://doi.org/10.4324/9781315268545 
Table 1: Descriptive statistics of study sample

\begin{tabular}{|c|c|c|c|}
\hline \multirow{2}{*}{ Sociodemographic variables } & \multicolumn{3}{|c|}{ Perception of public service } \\
\hline & Mean & Std. Dev. & $\mathrm{N}(\%)$ \\
\hline Overall & 2.12 & 0.61 & $505(100.0)$ \\
\hline \multicolumn{4}{|l|}{ Respondents' categories } \\
\hline Final year undergraduates & 1.95 & 0.50 & $101(20.0)$ \\
\hline Fresh graduates & 2.07 & 0.59 & $101(20.0)$ \\
\hline Public paid workers & 2.32 & 0.62 & $101(20.0)$ \\
\hline Private paid workers & 2.15 & 0.63 & $101(20.0)$ \\
\hline Self-employed & 2.09 & 0.64 & $101(20.0)$ \\
\hline \multicolumn{4}{|l|}{ Sex } \\
\hline Male & 2.06 & 0.57 & $259(51.29)$ \\
\hline Female & 2.17 & 0.64 & $246(48.71)$ \\
\hline \multicolumn{4}{|c|}{ Age $($ Mean $=29.53 ;$ SD=7.06; Median $=28)$} \\
\hline $18-20$ years & 2.00 & 0.51 & $54(10.69)$ \\
\hline $21-25$ years & 2.06 & 0.61 & $123(24.36)$ \\
\hline 26-30 years & 2.09 & 0.60 & $127(25.15)$ \\
\hline 31-35 years & 2.33 & 0.59 & $71(14.06)$ \\
\hline $36-40$ years & 2.12 & 0.63 & $130(25.74)$ \\
\hline \multicolumn{4}{|l|}{ Highest level of education } \\
\hline Primary & 1.85 & 0.07 & $2(0.4)$ \\
\hline Secondary & 2.12 & 0.62 & $40(7.92)$ \\
\hline Tertiary & 2.12 & 0.61 & $463(91.68)$ \\
\hline
\end{tabular}


Table 2. Descriptive statistics of the 10-item PPSQ-scale

\begin{tabular}{lllll}
\hline S/N & \multicolumn{1}{c}{ Items } & Mean & Std. Dev. & Median \\
\hline q1 & $\begin{array}{l}\text { Good working conditions are well provided in the } \\
\text { Nigerian public service }\end{array}$ & 2.13 & 0.78 & 2 \\
q2 & $\begin{array}{l}\text { Public workers are paid more than any other categories } \\
\text { of workers in Nigeria }\end{array}$ & 2.07 & 0.86 & 2 \\
q3 & $\begin{array}{l}\text { There are provisions for training and education in the } \\
\text { Nigerian public service }\end{array}$ & 2.23 & 0.73 & 2 \\
q4 & $\begin{array}{l}\text { There is job security in the Nigerian public service } \\
\text { q5 }\end{array}$ & $\begin{array}{l}\text { Workers are promptly promoted in the Nigerian public } \\
\text { service }\end{array}$ & 0.21 & 0.74 \\
q6 & $\begin{array}{l}\text { High rate of corruption/bad behaviour is recorded in } \\
\text { the Nigerian public service }\end{array}$ & 2.83 & 0.81 & 2 \\
q7 & $\begin{array}{l}\text { There is high record of lateness in the Nigerian public } \\
\text { service }\end{array}$ & 1.96 & 0.78 & 2 \\
q8 & $\begin{array}{l}\text { There is high productivity, effectiveness and } \\
\text { efficiency in the Nigerian public service }\end{array}$ & 1.96 & 0.75 & 2 \\
q9 & $\begin{array}{l}\text { Recruitment into the Nigerian public service is solely } \\
\text { based on merit }\end{array}$ & 1.88 & 0.83 & 2 \\
q10 & $\begin{array}{l}\text { Workers in the Nigerian public service are strictly } \\
\text { supervised }\end{array}$ & 2.03 & 0.74 & 2 \\
\hline
\end{tabular}


Table 3. Principal component and reliability analyses for PPSQ-scale

\begin{tabular}{llcc}
\hline Factors and corresponding items & $\begin{array}{c}\text { Rotated factor } \\
\text { loadings }\end{array}$ & \begin{tabular}{c} 
KMO \\
\cline { 2 - 2 }
\end{tabular} & $\begin{array}{c}\text { Cronbach's Alpha } \\
\text { if Item Deleted }\end{array}$ \\
\hline
\end{tabular}

Operation $($ Mean $=1.931, \mathrm{SD}=0.70034)$

$\begin{array}{llll}\text { q6 } & \mathbf{. 9 0} & .90^{\mathrm{a}} & .92 \\ \text { q7 } & \mathbf{. 8 7} & .94^{\mathrm{a}} & .92 \\ \text { q8 } & \mathbf{. 8 7} & .93^{\mathrm{a}} & .92 \\ \text { q9 } & \mathbf{. 8 6} & .94^{\mathrm{a}} & .93 \\ \text { q10 } & \mathbf{. 8 1} & .93^{\mathrm{a}} & .93\end{array}$

Reward $($ Mean $=2.299, \mathrm{SD}=\mathbf{0 . 6 4 0 5 8})$

\begin{tabular}{llll} 
q3 & $\mathbf{. 7 8}$ & $.90^{\mathrm{a}}$ & .77 \\
q5 & $\mathbf{7 6}$ & $.93^{\mathrm{a}}$ & .77 \\
q1 & $\mathbf{7 5}$ & $.92^{\mathrm{a}}$ & .77 \\
q2 & $\mathbf{. 7 5}$ & $.94^{\mathrm{a}}$ & .78 \\
q4 & .56 & $.67^{\mathrm{a}}$ & .95 \\
\hline
\end{tabular}

$\alpha(=.919) \quad .939 \quad .865$

\section{Before rotation}

$\begin{array}{lll}\text { Eigenvalues } & 6.339 & 1.277\end{array}$

\% of variance (76.161) $\quad 63.392 \quad 12.769$

After rotation

$\begin{array}{lrr}\text { Eigenvalues } & 4.752 & 2.864\end{array}$

$\%$ of variance (76.161) $47.525 \quad 28.636$

a. Measures of Sampling Adequacy (MSA); KMO=.92

Note: Factor loadings above .55 appear in bold 
Table 4. One-sample t-test of the extracted factors from the PPSQ-scale

\begin{tabular}{lcccccc}
\hline \multicolumn{1}{c}{ Extracted factors } & Mean & $\begin{array}{c}\text { Std. } \\
\text { Error }\end{array}$ & SD & $t$ & $\begin{array}{c}\text { Mean } \\
\text { difference }\end{array}$ & $\begin{array}{c}\text { Effect size } \\
(d)\end{array}$ \\
\hline Operational system & 1.9311 & .03116 & .70034 & $-6.062^{* * *}$ & -.18891 & -.27 \\
Reward system & 2.2994 & .02851 & .64058 & $6.294^{* * *}$ & .17941 & .28 \\
${ }^{* * * *} \mathrm{p}<0.001$ & & & & & &
\end{tabular}


Table 5. Mean comparison of extracted factors across sex and categories of occupation

\begin{tabular}{|c|c|c|c|c|c|c|c|c|c|}
\hline & \multirow{2}{*}{ Variables } & \multicolumn{4}{|c|}{ Operation } & \multicolumn{4}{|c|}{ Reward } \\
\hline & & Mean & SD & SE & $\mathrm{F}$ & Mean & SD & SE & $\mathrm{F}$ \\
\hline \multirow{2}{*}{ Sex } & Male & 1.88 & .67 & .042 & \multirow{2}{*}{2.314} & 2.24 & .60 & .037 & \multirow{2}{*}{$3.888^{*}$} \\
\hline & Female & 1.98 & .73 & .047 & & 2.36 & .67 & .043 & \\
\hline \multirow{5}{*}{$\begin{array}{l}\text { Respondent } \\
\text {, categories }\end{array}$} & Final Year & 1.73 & .57 & .057 & \multirow{5}{*}{$6.450^{* * *}$} & 2.17 & .53 & .05 & \multirow{5}{*}{$3.054^{*}$} \\
\hline & Fresh graduates & 1.90 & .71 & .071 & & 2.24 & .56 & .056 & \\
\hline & Public paid workers & 2.21 & .69 & .069 & & 2.42 & .64 & .063 & \\
\hline & Private paid workers & 1.90 & .70 & .070 & & 2.41 & .73 & .073 & \\
\hline & Self-employed & 1.91 & .74 & .073 & & 2.26 & .69 & .069 & \\
\hline
\end{tabular}

${ }^{*} \mathrm{p}<.05,{ }^{* * *} \mathrm{p}<.001$ 